\title{
The Effect of Orchis anatolica Leaves on Reproductive System-An in Vivo Study
}

\author{
Mansour M. Nawasreh \\ Department of Physics and Applied Sciences, Faculty of Engineering Technology, Al-Balqa Applied University, \\ Amman-Jordan \\ Email: nawasreh@bau.edu.jo,mansreh@yahoo.com \\ Lubna H.Tahtamouni \\ Department of Biology and Biotechnology, Faculty of Science, the Hashemite University, Jordan \\ Email: lubnatahtamuni@hu.edu.jo
}

\begin{abstract}
Modern medicine recognized Herbalism as an alternative therapy, though it is still widely used without supporting scientific evidence. Recent studies showed that the ingestion of Orchis anatolica roots enhanced adult male mice fertility. In the current study we aimed to investigate if the leaves of Orchis anatolica have fertility-enhancing effects similar to those of the root. As a result, sperm count, progressive motility and normal morphology were decreased in Orchis anatolica-treated group, while the percentage of sperm with damaged DNA increased. Additionally, the rate of pregnancy and the number of implantation sites decreased significantly in the treated group, while the number of resorption sites increased. Moreover, testosterone concentration decreased in Orchis anatolica-receiving group. This led to a conclusion that Orchis anatolica leaves ethanolic extract has a negative impact on male mice fertility.
\end{abstract}

Index Terms-fertility, Orchids anatolica, spermato-genesis, testosterone.

\section{INTRODUCTION}

For centuries, plants have been the base of medicinal treatment. The study or practice of medicinal and therapeutic properties of plants has been called Herbalism (also called phytomedicine or phytotherapy). [1] Modern medicine recognized Herbalism as an alternative therapy; but still it is widely used without strict scientific evidence [2]-[4].

Plants synthesize phytochemicals to perform important biological functions and to defend themselves against predators attacks [5]. In addition, those phytochemicals have beneficial effects on long-term health, and they can be used to effectively treat human diseases and dysfunctions [6], [7].

According to World Health Organization (WHO), about $35 \%-50 \%$ of infertility cases are due to male reproduction deficiencies [8]-[10]. Though some people do not believe in using plant-derived recipes to improve fertility and sexuality, many others used them through

Manuscript received December 6, 2016; revised April 21, 2017. centuries to improve their sexual life [11]. The components of these herbal recipes differ from one place to another with regard to the herb species that are most common to an area [11], [12]. Peanuts, papita, Chinese chive, and various types of orchids have been used because of their aphrodisiac effects [13]. People commonly ingest special parts of tuberous roots or fleshy leaves of orchids to enhance their fertility [11]-14].

As Orchidaceae is the largest family of flowering plants, and due to its large distribution in many countries and the erotic appearance of the flower, they have been and still widely used as aphrodisiac [15]. The word orkhis in Greek means testicle, and this name was given to this family because of the tuberous root appearance of the terrestrial species. Greeks believed that orchids influence sexuality, and they also believed that they could control the sex of their unborn babies; if the father ate large new tubers the baby would be male, while if mother ate small tubers the baby would be female [16].

Chemical study of different plants belonging to the Orchidaceae family showed the isolation of different phenolic compounds (I-V) as shown in Fig. 1. For example, 4-hydroxybenzyl alcohol (I), 4- $\beta$-Dglucopyranosyloxybenzyl alcohol (II) and 4hydroxybenzyl methyl ether (III) in addition to flavones and cumarines which were isolated from Orchis militaris [17]-[19]. Moreover, the cyanidin 3-O- $\beta-(6 "-O-o x a l y l)$ glucoside (IV) was isolated from flowers of orchids [20]. The loroglossin (V) in addition to different flavonoid glycosides were isolated from an aqueous ethanolic extract of Orchis papilionacea leaves [21]. Orchis anatolica grows mostly in countries such as Greece, Turkey, Syria, Lebanon, Iraq, Iran and Jordan. Recent studies showed that the ingestion of Orchis anatolica roots enhanced adult male mice fertility, increased the number of pregnant females, and increased the male:female offspring ratio [22], [23]. In this study we aimed to investigate if Orchis anatolica leaves ethanolic extract has any fertility-enhancing effects similar to those of the root. 


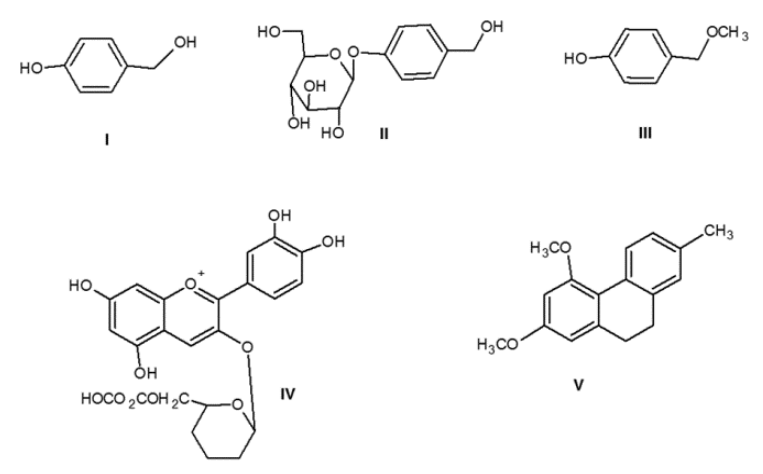

Figure 1. Chemical structures of some isolated compounds from the family Orchidaceae.

\section{EXPERIMENTAL}

\section{A. Orchis Anatolica Leaves Collection and Extraction}

The leaves of Orchis anatolica, known locally as orchid Al-Anadol [24], [25], were collected during the spring (March-April) of 2012 from Jerash mountains, Jordan. Fresh $O$. anatolica leaves were washed under running tap water, air dried (away from light), and then were grounded and extracted in ethanol. The solvent was evaporated to dryness at room temperature under atmospheric pressure, and the yield was $10 \% \mathrm{~m} / \mathrm{m}$. The resultant residue was dissolved in distilled water.

\section{B. Screening of the Chemical Constituents Of the Ethanolic Extract of Orchis Anatolica Leaves}

Gas Chromatography-Mass Spectroscopy (GC-MS) (AGLENT GC-MS and NIST Library) was used to determine the chemical composition of $O$. anatolica.

\section{Animal Treatment}

Twenty mature and healthy Balb/C male mice weighing between 25-30 gm were provided from the animal house of The Hashemaite University, Zarqa, Jordan. The animals were individually housed in cages and maintained under standard conditions (12 h light/ 12 $\mathrm{h}$ dark cycle; $25^{\circ} \mathrm{C}$ ) and had free access to tap water and food. After one week of acclimatization (WHO, 1983), the mice were randomly divided into two groups (control and treated). As in the previous study, the treated group was gavaged with $0.1 \mathrm{gm} /$ day/mouse of the crude ethanolic extract of Orchis anatolica leaves [22], while the second group (control) received distilled water. The dose was given orally using a gavage needle for 35 consecutive days (WHO, 1983).

\section{Fertility Test}

On day 30 of the treatment, control and treated male mice were cohabited for 5 days with fertile proestrus females weighing 25-30 gm in a 1:2 ratio, respectively. Successful mating was confirmed by the presence of a typical mating plug and/or sperms in the vaginal smear. When sperms were found in the smears indicating a positive mating, the females were separated and were given free access to food and water with daily monitoring of abdominal size. On day 16 of the pregnancy, 10 female mice of each group were killed and dissected. The implantation and resorption sites within the uterus were recorded. The other 10 females were allowed to complete their pregnancy. At the end of the pregnancy period, the number of pups delivered and their characteristics and sex were noted [2], [26], [27].

\section{E. Collection and Processing of Samples-Male Mice Autopsy}

On day 36 of treatment, the weights of the animals were recorded. The animals were then sacrificed by cervical dislocation, after which blood was collected by heart puncture. The blood was centrifuged at $2000 \mathrm{rpm}$ for $10 \mathrm{~min}$ and the supernatant (serum) was stored at -20 ${ }^{\circ} \mathrm{C}$ until use. In addition, the testes, seminal vesicles, and prostates were collected and weighed.

\section{F. Processing of Samples - Testosterone Evaluation}

Total serum testosterone was determined using testosterone Immulite immunoassay (Immulite 1000 Immunoassay Analyzer, Siemens Healthcare).

\section{G. Statistical Analysis}

Results were expressed as mean \pm standard deviation (SD). Student's t-test was used to test for significant difference between mean values of the two groups. A value of $\mathrm{p}<0.05$ was considered as statistically significant.

\section{RESULTS}

A. GC-MS of Some the Chemical Constituents of Orchis Anatolica Leaves Ethanolic Extract

Gas Chromatography-Mass Spectroscopy (GC-MS) analysis of $O$. anatolica leaves ethanolic extract revealed several peaks (see Fig. 2) corresponding to various compounds (see Table I).

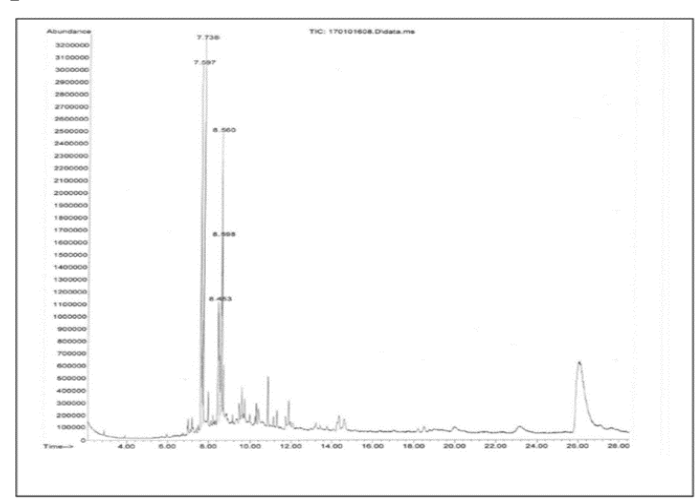

Figure 2. GC-MS analysis of $O$. anatolica leaves ethanolic extract.

TABLE I. GC-MS RESULTS OF SOME FRACTIONS OF O. ANATOLICA

\begin{tabular}{|c|c|}
\hline Compound & Retention time (min) \\
\hline n-Hexadecanoic acid & 7.59 \\
\hline Dibutyl phthalate & 7.67 \\
\hline Hexadecanoic acid, ethyl ester & 7.74 \\
\hline 9,12-Octadecadienoic acid (z,z) & 8.45 \\
\hline 9,12,15-Octadecatrienoic acid & 8.49 \\
\hline 9,12-Octadecadienoic acid, ethyl ester & 8.56 \\
\hline
\end{tabular}




\section{B. Fertility Test}

The results of the mating test showed that the percentage of pregnant females in the control group was $95 \%(19 / 20)$, while it decreased significantly $(\mathrm{p} \leq 0.05)$ to $65 \%(13 / 20)$ in the treated group (Table II). The average number of implantation and resorption sites in the control group was 9.4 and 0.67 , respectively. On the other hand, the average number of implantation sites in the treated group decreased significantly $(\mathrm{p}<0.05)$, while the average number of resorption sites increased but insignificantly ( $>0.05)$ (Table III). In the control group, the 10 pregnancies resulted in 78 viable mice offspring (7.8/pregnant female), while in the treated group the 7 pregnancies resulted in 38 mice offspring (5.4/pregnant female) $(\mathrm{p}<0.01)$ (Table II). The ratio of male to female mice offspring did not change significantly $(\mathrm{p}>0.05)$ between the control and treated group (Table II).

\section{The Effect of Orchis Anatolica Extract on Sperm Parameters Sperm Count, Motility, and Morphology}

Treatment of male mice with the crude ethanolic extract of Orchis anatolica leaves resulted in a significant decrease in sperm concentration $\left(44.7 \pm 3.2 \times 10^{6} \mathrm{sperm} / \mathrm{ml}\right)$ as compared to the control group $\left(69.3 \pm 4.9 \times 10^{6} \mathrm{sperm} / \mathrm{ml}\right)$ $(p<0.001)$. The average percentage of sperm showing progressive motility showed a marked decrease in the treated group $(74.2 \pm 5.1 \%)$ in comparison to the control group $(88.5 \pm 4.9 \%)(\mathrm{p}<0.001)$. The percentage of sperm with normal morphology decreased significantly in the treated group $(79.1 \pm 6.8 \%)$ as compared to the control group $(95.4 \pm 2.5 \%)(\mathrm{p}<0.001)$.

\section{D. -Testosterone evaluation}

Significant decline $(\mathrm{p}<0.01)$ in serum testosterone level was observed in the Orchis anatolica-receiving group $(1.24 \pm 0.29 \mathrm{ng} / \mathrm{ml})$ when compared with control group $(4.54 \pm 0.75 \mathrm{ng} / \mathrm{ml})$.

\section{DISCUSSION}

Documents dating as far as 4000 B.C. from areas around Euphrates, Babylon, and Egypt show that these civilizations used thyme, senna, cinnamon, and garlic as medicinal plants. Other nations such as the Chinese and the Indians also practiced Herbalism [1], [28], [29].

The results presented in this study show that the ethanolic extract of Orchis anatolica leaves have antifertility effects. Treatment of adult male mice with this extract for 35 consecutive days caused a reduction in pregnancy rate, number of implantation sites, and number of delivered fetuses/pregnant female (see Table II and Table III).

TABLE II. FERTILITY TEST RESUltS-A

\begin{tabular}{|c|c|c|c|}
\hline \multirow{2}{*}{$\begin{array}{c}\text { 16 Days } \\
\text { Post Mating }\end{array}$} & Group & \% Pregnancy & $\begin{array}{c}\text { Average No. of } \\
\text { Resorption } \\
\text { Sites }\end{array}$ \\
\cline { 2 - 4 } & $\begin{array}{c}\text { Average No. of } \\
\text { Implantation Sites }\end{array}$ & $.4 \pm 3.3$ \\
\cline { 2 - 4 } & $\begin{array}{c}\text { Treated } \\
(\mathrm{n}=10)\end{array}$ & $60 \%$ & $7.0 \pm 1.9^{\mathrm{a}}$ \\
\hline
\end{tabular}

TABLE III. Fertility Test Results-B

\begin{tabular}{|c|c|c|c|c|c|}
\hline \multirow{2}{*}{$\begin{array}{c}\text { Post } \\
\text { Delivery }\end{array}$} & Group & \% Pregnancy & $\begin{array}{c}\text { verage No. of } \\
\text { Offspring }\end{array}$ & $\begin{array}{c}\text { Average No. of Male } \\
\text { Offspring }\end{array}$ & $\begin{array}{c}\text { Average No. } \\
\text { of Female } \\
\text { Offspring }\end{array}$ \\
\cline { 2 - 5 } & $\begin{array}{c}\text { Control } \\
(\mathrm{n}=10)\end{array}$ & $100 \%$ & $7.8 \pm 1.5$ & $\begin{array}{c}3.8 \pm 1.4 \\
(48.7 \%)\end{array}$ \\
\cline { 2 - 5 } & $\begin{array}{c}\text { Treated } \\
(\mathrm{n}=10)\end{array}$ & $70 \%^{\mathrm{a}}$ & $5.4 \pm 1.5^{\mathrm{b}}$ & $\begin{array}{c}2.9 \pm 1.0 \\
(50.9 \%)\end{array}$ \\
\hline
\end{tabular}

$*$ a $\mathrm{p}<0.05$ versus control, $\mathrm{b} \mathrm{p}<0.01$ versus control

Treated mice testicular sections exhibited spermatogenesis late maturation arrest which in turn caused low sperm concentration. One possible explanation for this arrest is the reduction in the number of interstitial Leydig cells causing a reduction in testicular testosterone level [30], [31]. It is generally accepted that the proliferation of germinal epithelium is androgen-dependent [32]. In addition, it was noticed that some germ cells (round spermatids) were sloughed into the lumen of the seminiferous tubules of treated mice. Adhesion between germ cells and Sertoli cells may be androgen- dependent. Testosterone withdrawal leads not only to retention and phagocytosis of mature, elongated spermatids, but also to premature release of round spermatids [33].

\section{CONCLUSION}

Based on the results of the current work, we conclude that the ethanolic extract of the leaves of Orchis anatolica exerted anti-fertility effects. Many people of different cultures are still using traditional medicines to treat reproductive disorders such as infertility and impotency. However, there is an urgent need for extensive pre- and clinical investigations to validate traditional claims. Otherwise, the improper use 
of herbal medicine could lead to acute or chronic toxicity.

The sub-fractions of roots ethanolic extracts for studying different fertility parameters are now under investigation.

\section{ACKNOWLEDGMENT}

The authors are grateful for Dr. Amjad Mahasneh and Ms. Najah Obeidat, Jordan University for Science and Technology for their help with Gas ChromatographyMass Spectroscopy (GC-MS) analysis and for Ms. Zainab Al-Mazaydeh for her technical help.

The current work was funded by the Deanship of Scientific Research, Al-Balqa Applied University.

\section{REFERENCES}

[1] S. Y. Pan, et al., "Historical perspective of traditional indigenous medical practices: The current renaissance and conservation of herbal resources," Evid. Based Compl. Alt., vol. 1, pp. 1-20, 2014.

[2] WHO, "Protocol MB-50, a method for examining the effect of the plant extracts administered orally on the fertility of male rats," Geneva World Health Organization, 1983.

[3] WHO, "Guidelines for the assessment of herbal medicines," Geneva World Health Organization, 1991.

[4] P. A. DeSmet, "Should herbal medicine-like products be licensed as medicines," Br. Med. J., vol. 310, pp. 1023-1024, 1995.

[5] A. Elumalai and M. C. Eswariah, "Herbalism-A review," Inter. J. Phytother., vol. 2, pp. 96-105, 2012.

[6] K. B. Pandey and S. I. Rizvi, "Plant polyphenols as dietary antioxidants in human health and disease," Oxid. Med. Cell Longev., vol. 2, pp. 270-278, 2009.

[7] R. P. Samy and P. Gopalakrishnakone, "Therapeutic potential of plants as anti microbials for drug discovery," Evid.-Based Compl. Alt., vol. 7, pp. 283-294, 2010.

[8] A. Hirsh, "Male subfertility," Br. Med. J., vol. 327, pp. 669-672, 2003.

[9] V. M. Brugh and L. I. Lipshultz, "Male factor infertility: Evaluation and management," Med. Clin. North Am., vol. 88, pp. 367-385, 2004.

[10] M. N. Mascarenhas, S. R. Flaxman, T. Boerma, S. Vanderpoel, and G. A. Stevens, "National, regional, and global trends in infertility prevalence since 1990: A systematic analysis of 277 health surveys," PLoS Med., vol. 9, p. e1001356, 2012.

[11] N. S. Chauhan, V. Sharma, V. K. Dixit, and M. Thakur, "A review on plants used for improvement of sexual performance and virility," Biomed. Res. Int., vol. 1, pp. 1-19, 2014.

[12] M. Thakur, N. S. Chauhan, S. Bhargava, and V. K. Dixit, "A comparative study on aphrodisiac activity of some ayurvedic herbs in male albino rats," Arch. Sex. Behav., vol. 38, pp. 1009-1015, 2009.

[13] R. Singh, S. Singh, G. Jeyabalan, and A. Ali, "An overview on traditional medicinal plants as aphrodisiac agent," J. Pharm. Phytochem., vol. 1, pp. 43-56, 2012.

[14] M. Thakur and V. K. Dixit, "Aphrodisiac activity of Dactylorhiza hatagirea (D.Don) Soo in male albino rats," Evid.-Based Compl. Alt., vol. 4, pp. 29-31, 2007.

[15] M. F. Fay and M. W. Chase, "Orchid biology: From Linnaeus via Darwin to the $21^{\text {st }}$ century," Annals of Botany, vol. 104, no. 3, pp. 359-364, 2009.

[16] Center for Research in Reproduction and Contraception. The Orchid in the Human Imagination. [Online]. Available: http://depts.washington.edu/popctr/orchids.htm

[17] Japanese patent JP 57048910 A 19820320, 1982.
[18] Japanese patent JP 57048913 A 19820320, 1982

[19] C. Appolonia, A. Marston, and K Hostettmann, "Additional constituents of Orchis militaris," J. Nat. Prod., vol. 49, pp. 725$725,1986$.

[20] D. Strack, E. Busch, V. Wray, L. Grotjahn, and E. Klein, "Cyanidin 3-oxalylglucoside in orchids," Zeitschrift für. Naturforschung C., vol. 41, pp. 707-711, 1986.

[21] F. Pagani, "Phytoconstituents of Orchidaceae II: Isolation and identification of loroglossin and of some flavonol heterosides from Orchis papilionacea L.," Boll. Chim. Farm., vol. 121, pp. 174-177, 1982.

[22] N. A. Khouri, M. Nawasreh, S. M. Al-Hussain, and A. S. Alkofahi, "Effects of orchids (Orchis anatolica) on reproductive function and fertility in adult male mice," Reprod. Med. Boil., vol. 5, pp. 269-276, 2006.

[23] M. Z. Allouh, N. A. Khouri, H. M. Daradka, and E. G. Kaddumi, "Orchis anatolica root ingestion improves sexual motivation and performance in male rats," J. Compl. Integ. Med., vol. 7, pp. 1-12, 2010.

[24] D. Al-Eisawi, Field Guide to Wild Flowers of Jordan and Neighboring Countries, Amman, Jordan: Al-Rai Press, 1998.

[25] S. Oran and D. Al-Eisawi, "Check-list of medicinal plants in Jordan," Dirasat., vol. 25, pp. 84-112, 1998.

[26] P. C. Mali, A. S. Ansari, and M. Chaturvedi, "Antifertility effect of chronically administered Martynia annua root extract on male rats," J. Ethnopharmacol., vol. 82, pp. 61-67, 2002.

[27] K. Narayana, J. A. D'Souza, and R. K. P. Seetharama, "Ribavirininduced sperm shape abnormalities in Wistar rat," Mutat Res., vol. 513, pp. 193-196, 2002.

[28] J. Nunn, Ancient Egyptian Medicine, London, UK: University of Oklahoma Press, 2002.

[29] J. Sumner, The Natural History of Medicinal Plants, Oregon, USA: Timber Press, 2000.

[30] R. I. McLachlan, N. J. Wreford, L. O. Donnell, D. M. D. Kretser, and D. M. Robertson, "The endocrine regulation of spermatogenesis: Independent roles for testosterone and FSH," $J$. Endocrinol., vol. 148, pp. 1-9, 1996.

[31] S. Jahan, et al., "Histomorphological study to evaluate antifertility effect of Abrus precatorius L. in adult male mice," J. Med. Plants Res., vol. 3, pp. 1021-1028, 2009.

[32] M. A. Rivarola, E. J. Podestá, H. E. Chemes, and R. S. Calandra, "Androgen metabolism and concentration in the seminiferous tubules at different stages of development," J. Steroid Biochem., vol. 6, pp. 365-369, 1975.

[33] W. R. Holdcraft and R. E. Braun, "Androgen receptor function is required in Sertoli cells for the terminal differentiation of haploid spermatids," Development, vol. 131, pp. 459-467, 2003.

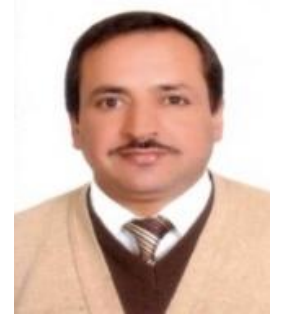

Dr. Mansour M. Nawasreh, Ph.D. in organic chemistry from Hannover University/ Germany in 2000. Associate Professor since 2011. Research Fields: Synthesis of bioactive cephalostatin analogues, investigation of biologically active medicinal plants. Address: Department of Physics and Applied Sciences, Faculty of Engineering Technology /Al-Balqa Applied University/ Amman-Jordan. P.B. 15008, Marka, 11134 Amman.

Dr. Luna Tahtamouni, Ph.D. in Biology from Colorado State University, 2005. Appointed at the Hashemite University since 2005. Associate Professor since 2012.

Dept. of Biology and Biotechnology, Faculty of Science, The Hashemite University P.O. Box 150459, Zarqa 13115, Jordan. 